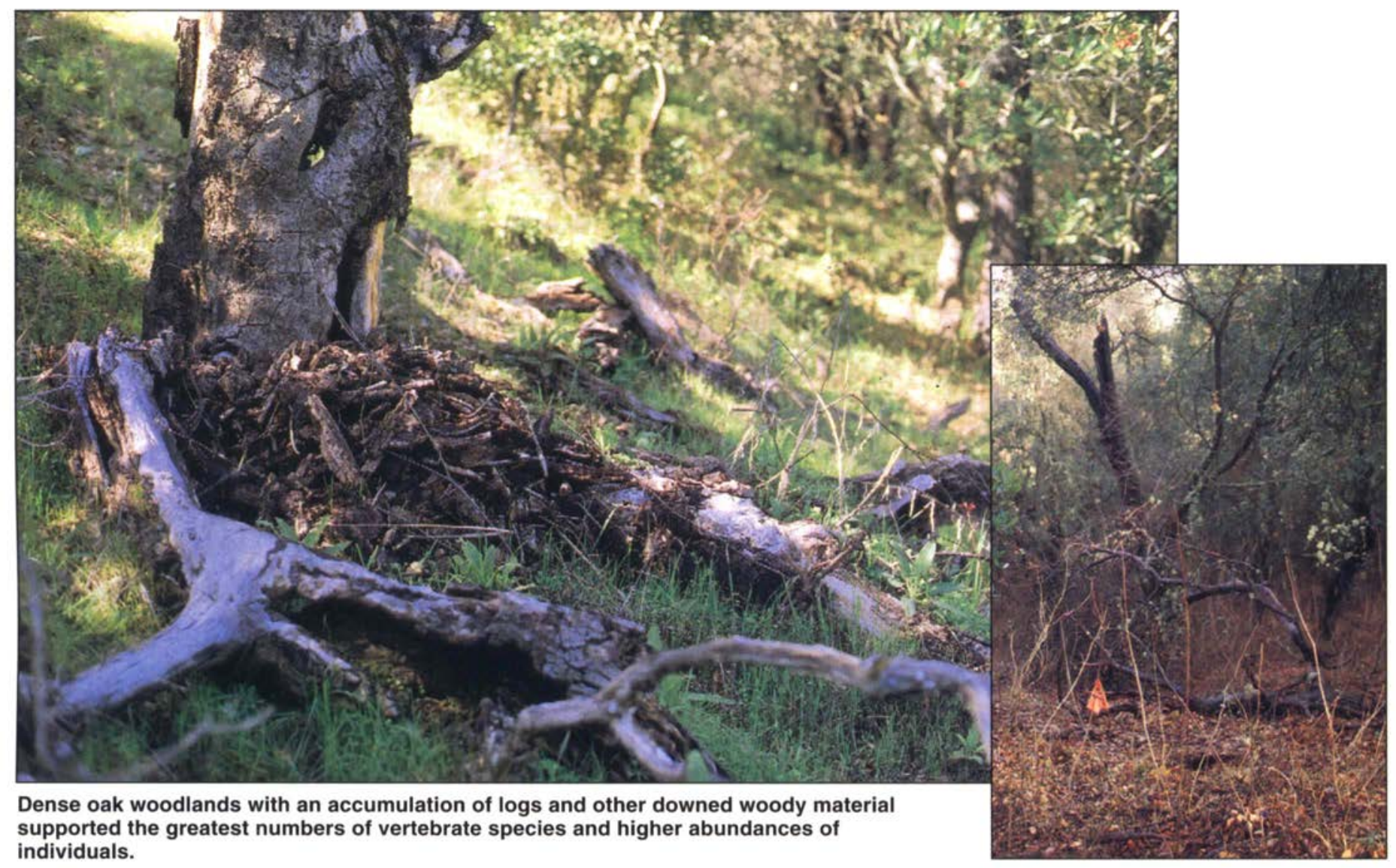

\title{
Vertebrates diverse and abundant in well-structured oak woodland
}

\author{
William D. Tietje $\quad$ Justin K. Vreeland
}

\begin{abstract}
Knowledge of the diversity and abundance of vertebrates in relatively undisturbed oak woodlands could be used as a baseline for evaluating natural and humancaused perturbations. High numbers of terrestrial vertebrates were found in well-structured oak woodland at a study site in the Central Coast region. Within classes of terrestrial vertebrates, woodrats, dark-eyed juncos and slender salamanders exhibited the strongest habitat associations. Dense oak woodlands with shrubby understory and downed woody material supported the greatest numbers of vertebrate fauna.
\end{abstract}

In much of California's 7 million acres of oak woodlands, grazing, wood cutting, row cropping, road building and development have altered the habitat to the extent that much understory vegetation and downed woody material have been removed. These alterations have had mostly unknown consequences on oak woodland fauna. Knowledge of the diversity and abundance of vertebrates in relatively unaltered woodlands could be used as a baseline for evaluating natural and anthropogenic disturbances in California oak woodland.

Camp Roberts, a military training site of the California Army National Guard, is located in northern San Luis Obispo and southern Monterey Coun- ties, 11 miles north of Paso Robles. The facility covers 43,800 acres, of which approximately 17,800 acres $(41 \%)$ are classified as oak woodland. Most of the woodland in the areas referred to as "the hill country," the steep, rugged southwestern part of the installation, receives minimal use by military personnel and is not managed for livestock, woodcutting or other land-use activities.

In the summer of 1993 , we established nine square 14-acre sampling plots. On each plot we laid out a grid comprised of 289 intersections. Beginning in fall 1993, we sampled small mammals, birds, amphibians, reptiles and vegetation on these plots. 


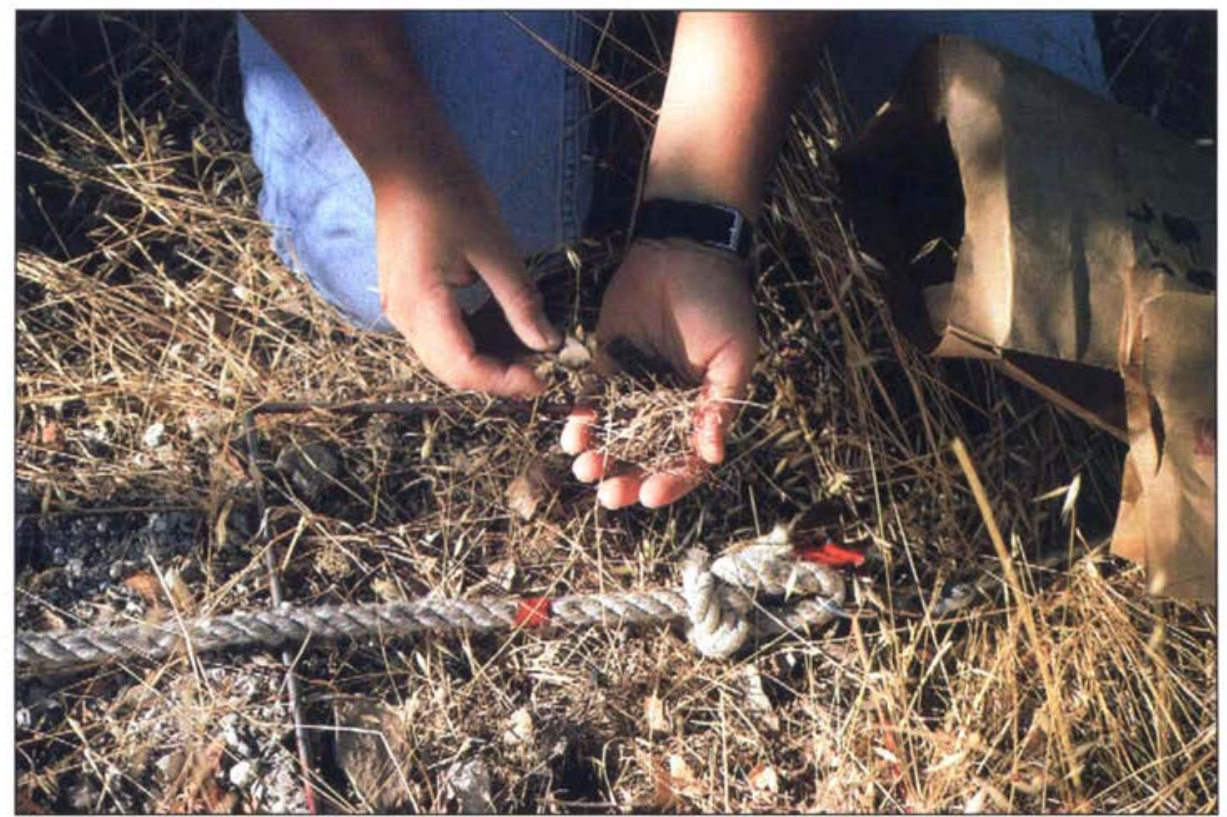

Above, researchers weighed samples of ground litter - dried grass, leaves and other vegetative debris - to determine habitat characteristics. Right, Stacy Small, a field assistant, helps record tree species, breast-height diameter of trees, number of saplings and vegetative cover of trees, shrubs, ground vegetation and downed wood.

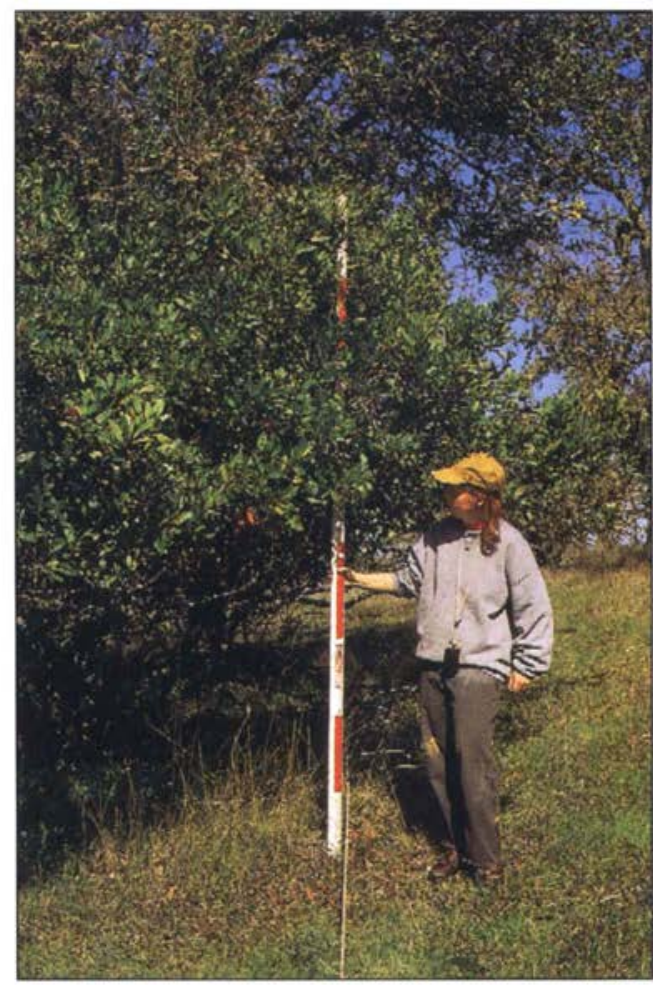

Our work at Camp Roberts is part of a long-term study to establish a baseline for relatively unperturbed oak woodland - that is, what abundances and diversities of vertebrates are possible in the absence of human intrusion. In addition, this study can be used to indicate what degraded habitats could support with appropriate habitat-improvement measures. The baseline data also will be used for evaluating the response of terrestrial vertebrates to a prescribed burn treatment, which was conducted in October 1997. This report highlights our baseline findings in oak woodland at Camp Roberts.

\section{Vegetation sampling}

In the spring and summer of 1995 , we sampled vegetation at grid intersections on each of the nine study plots. Using several vegetation sampling techniques, we recorded tree species; breast-height diameter (dbh); number of saplings; and vegetative cover of trees, shrubs, ground vegetation and downed wood. We also collected and weighed a sample of ground litter (grass, leaves and other vegetative debris) at each vegetation sampling intersection.

\section{Animal sampling}

Small mammal trapping was conducted in October 1993 and in October and May 1994-1996, for a total of 7 trapping sessions. A single Sherman live trap ( 3 inches by 4 inches by 12 inches) was placed at each of the 289 intersections on each of the nine study plots. Traps were baited and checked once daily after each of 5 consecutive nights. Captured animals were marked with uniquely numbered ear tags and released.

Two or three field biologists, trained to identify birds by sight and sound, recorded pairs of breeding birds during the springs of 1994-1996 by spot mapping. Spot mapping consisted of recording the species, location and activity of each detected bird along four evenly spaced grid lines in each study plot. Eight to 12 separate visits per plot were conducted each spring. After each field season, we used our field data to delineate (i.e., map) bird territories by species and study plot.

In 1994, we placed a single 0.5 -inchthick 24-inch-square plywood board ("coverboard") flush with the ground within 6 feet of each intersection on alternate grid lines on each plot. Every 7 to 10 days during late January through April of 1995 and 1996 we recorded the species and locations of amphibians and reptiles observed under the coverboards.

\section{Data analyses}

We used Spearman rank correlation $\left(r_{\mathrm{S}}\right)$ to assess habitat associations for the six most abundant ( $\geq 130$ individuals captured per 7 trapping sessions) small mammal species; four most abundant ( $\geq 10$ territories occurring on $\geq 8$ plots in $\geq 2$ years) bird species; and four most abundant ( $\geq 96$ observations) amphibian and reptile species. Species with strong positive or negative preference for certain habitat components should have high correlation 
coefficients, either negative or positive, with the variables that measure those habitat components. Therefore, we considered the vertebrate species with the highest average correlation coefficients to have the strongest habi-

\begin{tabular}{|c|c|c|}
\hline $\begin{array}{r}\text { TABLE 1. Habitat character } \\
\text { vegetation variables used to } \\
\text { associations of small mammal } \\
\text { and amphibians on nine 14-a } \\
\text { woodlands, Camp Roberts } \\
\text { summer } 1995\end{array}$ & $\begin{array}{l}\text { tics of } \\
\text { sess } \\
\text { birds, } \\
\text { plots } \\
\text { pring }\end{array}$ & $\begin{array}{l}\text { ine } \\
\text { bitat } \\
\text { eptiles } \\
\text { n oak } \\
\text { nd }\end{array}$ \\
\hline Habitat characteristic & Low & High \\
\hline Live tree density (stems/acre) ${ }^{*}$ & 321 & 1,139 \\
\hline Snag density (stems/acre) & 22 & 89 \\
\hline Tree canopy cover $(\%)$ & 40 & 70 \\
\hline Shrub cover $(\%)$ & 0 & 35 \\
\hline Grass cover $(\%)$ & 38 & 72 \\
\hline Forb cover $(\%)$ & 1 & 6 \\
\hline Downed wood cover (\%) & 1 & 6 \\
\hline Unvegetated ground (\%) & 8 & 15 \\
\hline Litter weight (lb/acre) & 816 & 2,670 \\
\hline
\end{tabular}

tat associations. Correlations were considered significant when $P \leq 0.05$.

\section{Habitat characteristics}

Across all nine study plots, stand composition was $56 \%$ to $100 \%$ blue oak and $0 \%$ to $44 \%$ coast live oak. Density of live trees (including saplings) ranged from 321 to 1,139 stems per acre, and density of standing dead trees (snags) ranged from 22 to 89 per acre (table 1). Live tree canopy and shrub cover ranged from $40 \%$ to $70 \%$ and $0 \%$ to $35 \%$ of plots, respectively. Grass, forbs, downed wood and unvegetated ground comprised the ground cover and varied among plots (table 1). Litter weight varied from 816 to 2,670 pounds per acre.
TABLE 2. Capture statistics of 10 species of small mammals captured in Sherman live traps on nine 14-acre plots in oak woodlands, Camp Roberts, spring and fall, fall 1993 to fall 1995

\begin{tabular}{lccc}
\hline \hline Species & $\begin{array}{c}\text { Total } \\
\text { captures }\end{array}$ & $\begin{array}{c}\text { Individual } \\
\text { captures }\end{array}$ & $\begin{array}{c}\text { Trap } \\
\text { success* }\end{array}$ \\
\hline Dusky-footed woodrat & 8,924 & 2,363 & 10.0 \\
Piñon mouse & 2,936 & 1,166 & 3.3 \\
California pocket mouse & 2,098 & 1,168 & 2.4 \\
Brush mouse & 1,903 & 956 & 2.1 \\
Deer mouse & 947 & 604 & 1.1 \\
California mouse & 422 & 130 & 0.5 \\
California vole & 116 & 91 & 0.1 \\
Merriam's chipmunk & 100 & 39 & 0.1 \\
Heermann's kangaroo rat & 52 & 18 & 0.1 \\
Western harvest mouse & 22 & 22 & $<0.1$ \\
Total & 17,520 & 6,557 & 19.7
\end{tabular}

- Trap success $=$ total captures expressed as a percentage of total trap-nights $(88,910)$.

TABLE 3. Spearman correlation matrix of relative abundance of selected vertebrate species and selected habitat variables measured on nine square 14-acre plots in oak woodland, Camp Roberts, 1993-1996

\begin{tabular}{|c|c|c|c|c|c|}
\hline Species & $\begin{array}{c}\text { Percent of } \\
\text { canopy } \\
\text { cover }\end{array}$ & $\begin{array}{c}\text { Percent of } \\
\text { shrub } \\
\text { cover }\end{array}$ & $\begin{array}{l}\text { Percent of } \\
\text { downed } \\
\text { wood } \\
\text { cover }\end{array}$ & $\begin{array}{l}\text { Percent of } \\
\text { unvegetated } \\
\text { ground } \\
\text { cover }\end{array}$ & $\begin{array}{l}\text { Litter } \\
\text { weight }\end{array}$ \\
\hline \multicolumn{6}{|l|}{ Small mammals } \\
\hline Dusky-footed woodrats & $0.68^{*}$ & $0.95^{\circ}$ & $0.90^{*}$ & 0.37 & 0.43 \\
\hline Piñon mice & 0.62 & $0.78^{*}$ & $0.69^{*}$ & 0.57 & 0.24 \\
\hline Brush mice & $0.68^{*}$ & 0.47 & 0.55 & 0.05 & 0.46 \\
\hline California pocket mice & 0.17 & 0.47 & 0.40 & 0.60 & -0.30 \\
\hline California mice & 0.63 & $0.98^{*}$ & $0.92^{*}$ & 0.26 & 0.41 \\
\hline Deer mice & -0.17 & 0.08 & -0.02 & $0.82^{*}$ & -0.35 \\
\hline \multicolumn{6}{|l|}{ Birds } \\
\hline Plain titmice & 0.45 & 0.27 & 0.20 & 0.28 & 0.11 \\
\hline Dark-eyed juncos & $0.82^{*}$ & $0.68^{*}$ & $0.77^{*}$ & -0.13 & $0.88^{*}$ \\
\hline House finches & 0.34 & 0.41 & 0.41 & 0.02 & 0.60 \\
\hline White-breasted nuthatches & -0.54 & $-0.72^{*}$ & $-0.77^{*}$ & 0.09 & -0.34 \\
\hline \multicolumn{6}{|l|}{ Amphibians } \\
\hline Slender salamanders & $0.83^{*}$ & 0.47 & 0.50 & 0.10 & 0.62 \\
\hline \multicolumn{6}{|l|}{ Reptiles } \\
\hline Gopher snakes & 0.39 & $0.69^{*}$ & $0.68^{*}$ & -0.11 & 0.64 \\
\hline Skinks & -0.18 & 0.17 & 0.24 & 0.47 & 0.18 \\
\hline Western fence lizards & 0.15 & 0 & 0.07 & 0.23 & 0.50 \\
\hline
\end{tabular}

- Asterisks denote significance at $\mathrm{P} \leq 0.05$

\section{Small mammals}

Species richness and numbers. During 88,910 trap-nights, we accumulated 17,520 captures of 6,557 individuals of 10 species of small mammals (table 2). Trap-nights, a measure of sampling effort, is calculated by multiplying the number of traps by the number of nights traps were open. Of the 6,557 individuals we captured, $36 \%$ were dusky-footed woodrats (Neotoma fuscipes), $18 \%$ were piñon mice (Peromyscus truei), $18 \%$ were California pocket mice (Perognathus californicus), $15 \%$ were brush mice (Peromyscus boylii), 9\% were deer mice (Peromyscus maniculatus) and $2 \%$ were California mice (Peromyscus californicus). Among these species, trap success (the number of captures per trapnight) was highest for woodrats ( $10.0 \%$ of all captures) and lowest for California mice ( $0.5 \%$ of all captures); average number of captures per animal was highest for wood rats (3.8) and lowest for deer mice (1.6). Four species had fewer than 400 captures per 7 trapping sessions (table 2). We occasionally captured California ground squirrels (Spermophilus beecheyi) and Botta's pocket gophers (Thomomys bottae), but did not record these captures.

Habitat relationships. California mice, woodrats and piñon mice were more abundant in areas with higher percentages of shrub cover, canopy cover and downed wood cover (fig. 1, table 3). Canopy cover was most important for brush mice (fig. 2), whereas shrub cover was most important for woodrats, California mice and piñon mice. Deer mice were more abundant where the ground was sparsely vegetated (fig. 3 ). Across all habitat variables, woodrat populations exhibited the strongest ties, whereas deer mice exhibited the weakest habitat relationships. California pocket mice were not significantly correlated with any habitat variable we measured.

\section{Birds}

\section{Species richness and numbers.}

We delineated territories for 23 bird species after 303 visits in the spring of each year, 1994 through 1996. Territo- 

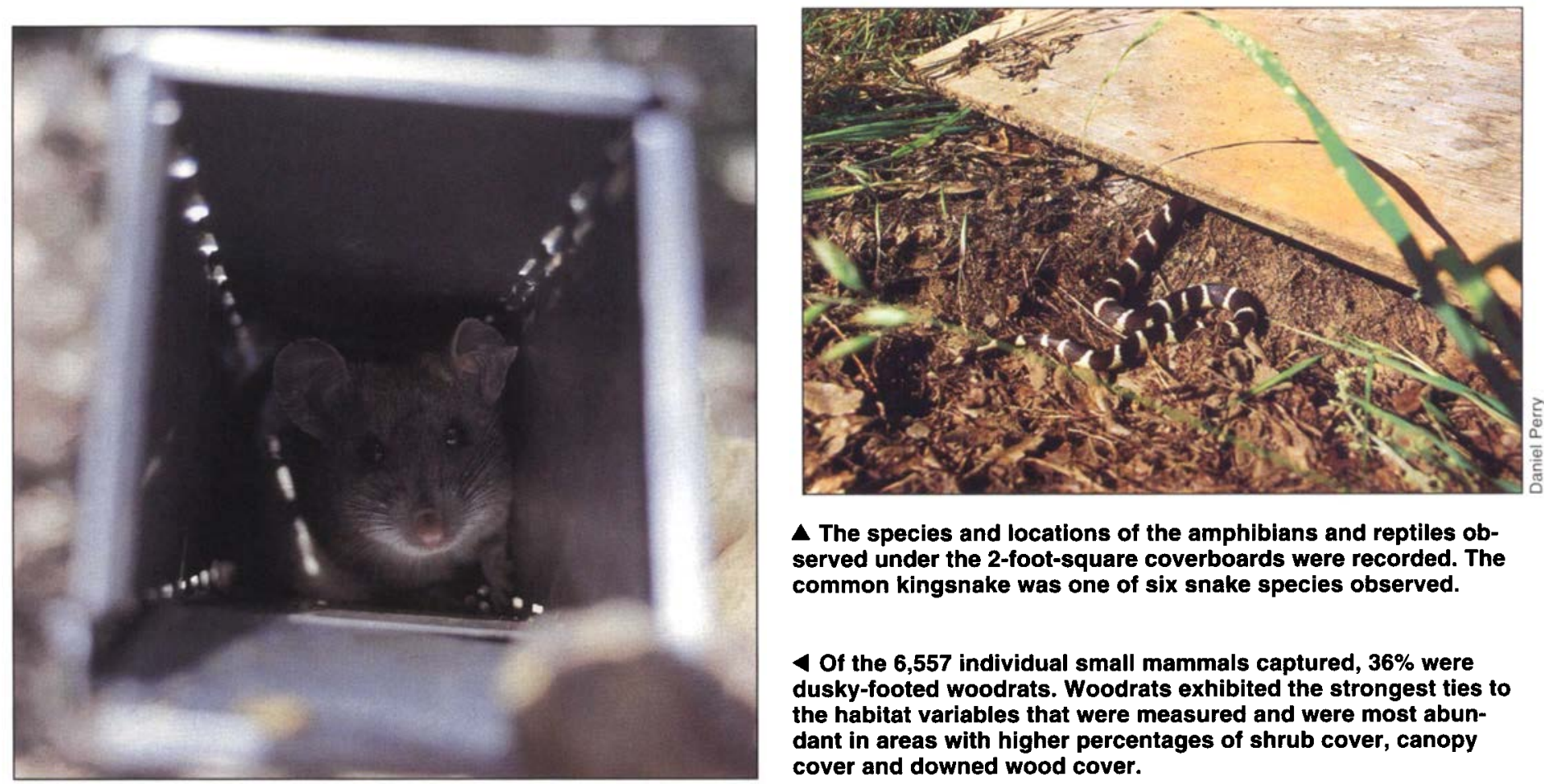

$\Delta$ The species and locations of the amphibians and reptiles observed under the 2-foot-square coverboards were recorded. The common kingsnake was one of six snake specles observed.

4 Of the 6,557 individual small mammals captured, $36 \%$ were dusky-footed woodrats. Woodrats exhibited the strongest ties to the habitat variables that were measured and were most abundant in areas with higher percentages of shrub cover, canopy cover and downed wood cover.

ries were not delineated for more than 50 other species for which fewer than 3 detections of each species were recorded per spring or because the species' behavior precluded such delineation - for example, scrub jays (Aphelocoma coerulescens). Plain titmice (Parus inoratus), dark-eyed juncos (Junco hyemalis), white-breasted nuthatches (Sitta carolinensis) and house finches (Carpodacus mexicanus) had the greatest number of territories on the study plots (table 4).

Habitat relationships. Trends in habitat use were inconsistent among the four most abundant species we observed at Camp Roberts (table 3 ).

However, areas with dense tree canopy, heavy shrub cover and deep litter were important for plain titmice, dark-eyed juncos and house finches.
Of the habitat variables we measured, litter weight was the habitat variable that most influenced the abundance of dark-eyed juncos (fig. 4) and house finches. Percent canopy cover was the most important habitat variable for plain titmice, whereas percent cover of downed woody material was the most important habitat variable for whitebreasted nuthatches (fig. 5). Juncos exhibited the strongest habitat relationships across all habitat variables. Plain titmice exhibited the weakest correlations across all habitat variables. Only dark-eyed juncos and white-breasted nuthatches were significantly correlated with any habitat variables.

\section{Amphibians and reptiles}

Species richness and numbers. We recorded 2,658 observations of 15 to 17 species of amphibians and reptiles during 33,728 coverboard checks in 1995 and 1996 (we probably recorded multiple observations of the same individual in some instances): 5 or 6 species of lizards, 2 or 3 salamanders, 6 snakes, 1 frog and 1 toad (table 5). Skinks (Eumeces skiltonianus and potentially E. gilberti), western fence lizards (Sceloporus occidentalis), slender salamanders (Batrachoseps nigriventris and potentially B. pacificus) and gopher snakes (Pituophis melanoleucus) were the four most abundant species, $40 \%, 24 \%, 19 \%$ and $4 \%$ of total observations, respectively, and $3.1 \%, 1.9 \%$, $1.5 \%$ and $0.3 \%$ of total possible observations, respectively. Eleven other species were observed fewer than 95 times.
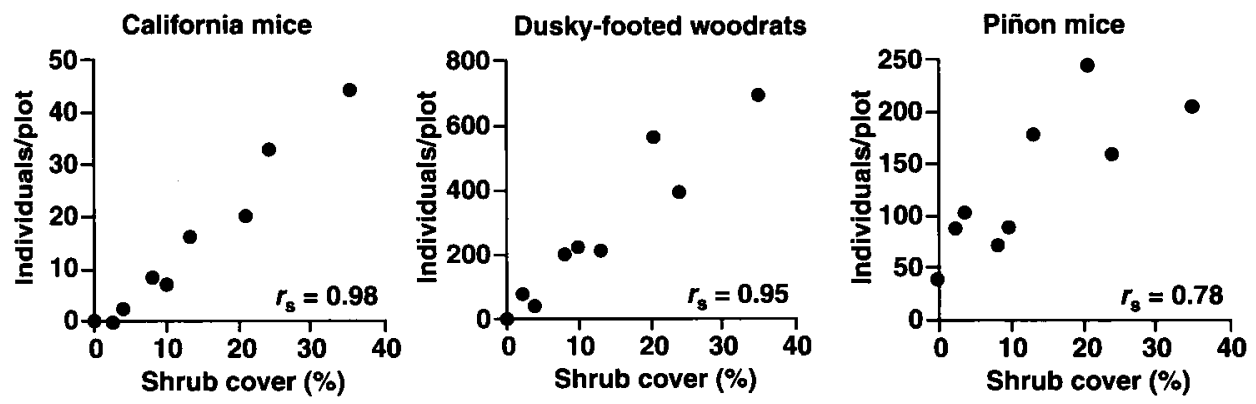

Fig, 1. Total number of individual California mice, dusky-footed woodrats and piñon mice captured per plot on nine 14-acre plots in blue oak woodlands of Camp Roberts during fall 1993 and spring and fall 1994-1996.

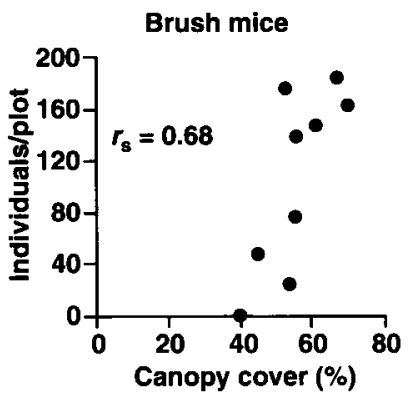

Fig. 2. Total number of individual brush mice captured per plot on nine 14-acre plots in blue oak woodlands of Camp Roberts during fall 1993 and spring and fall 1994-1996. 


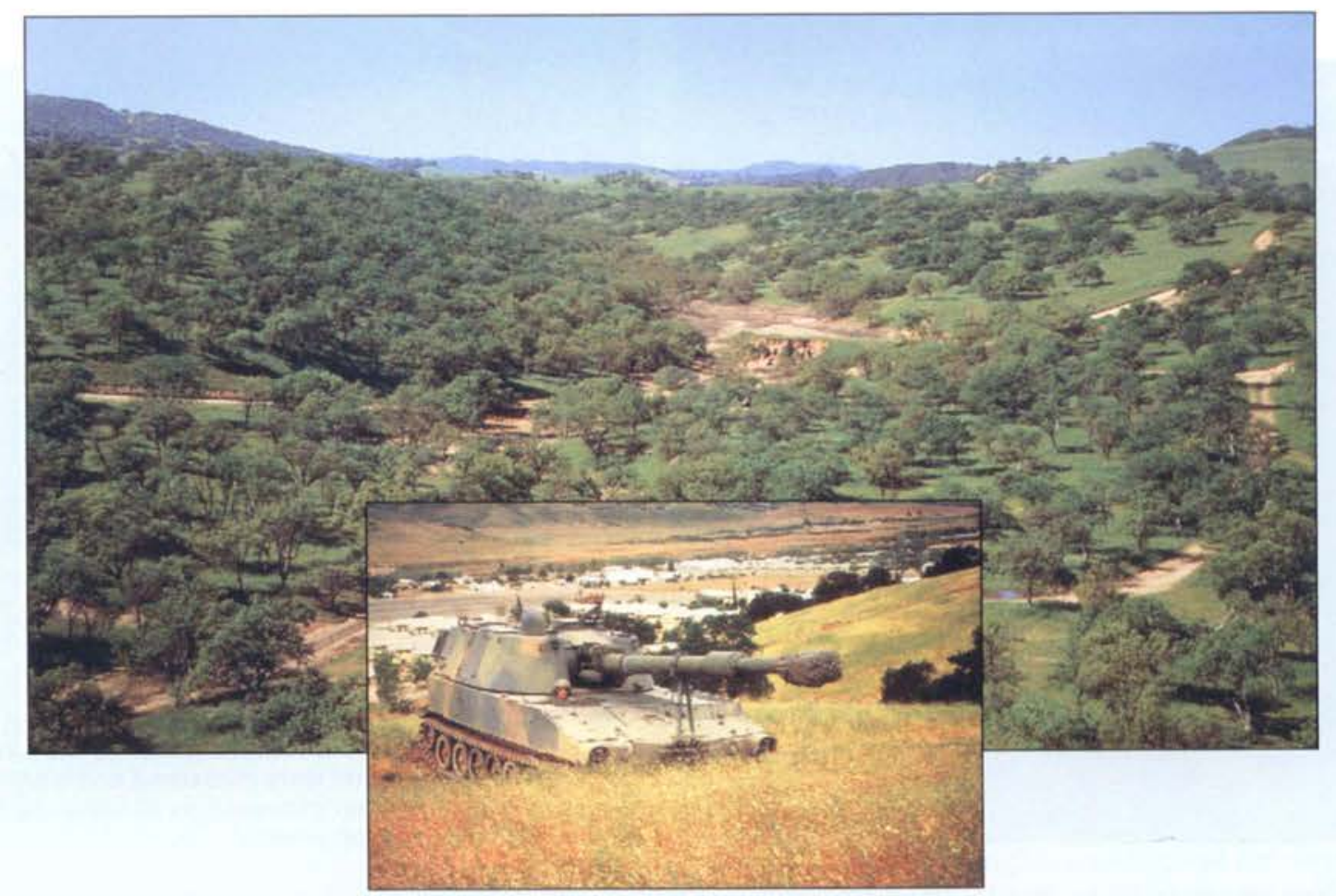

\section{Camp Roberts: Rockets and woodrats}

\section{Brian Duke}

Most people think of a military training site as a place pounded by heavy artillery and raked into a pitted moonscape by machine-gun fire. In certain areas, and at certain times, the Camp Roberts Military Training Site fits this description. At just under 43,000 acres, Camp Roberts is one of the smallest military training sites in the nation, but it is also one of the busiest, with approximately 300,000 person-days of training conducted in 1996. The site currently serves as a field maneuver and live-fire training facility for National Guard units, active and reserve elements of the Army, Navy, Air Force and Marine Corps, and federal, state and local lawenforcement agencies.

Yet amid the rumbling armored vehicles, numerous plant and animal species make Camp Roberts their home. Camp Roberts features dense oak forests, meandering rivers lined with willow and sycamore trees, steep slopes covered in chaparral, toyon and manzanita bushes, and large, open grasslands carpeted with spring wildflowers.

Because large land areas are required for some types of training, mili- tary training sites typically occupy vast, contiguous tracts of undeveloped land. Certain types of training actions degrade the environment, but their duration at Camp Roberts is brief. In many instances, areas that sustain intense activity for these 2-week periods may be virtually untouched for the rest of the year, allowing the land to recover naturally. The combination of these factors results in large, relatively undisturbed areas that support thriving plant and animal communities.

The Army National Guard also commits substantial resources to preserve and protect the environment, restore degraded areas and enhance habitats. In addition to complying with federal and state environmental laws, the Army National Guard requires its commanders and training site operators to help conserve natural resources and holds them accountable for mismanagement of environmental programs or failure to follow standards.

The Army National Guard has also taken steps to increase our knowledge of natural communities and has entered into cooperative agreements and partnerships to improve habitats and enhance wildlife. A natural resources and land management program, known as Integrated Training Area Management (TAM), was initiated at Camp Roberts in 1993. This program is based on the systematic survey of training lands and natural resources. The data from this survey are used to make informed management decisions. The program is dedicated to restoring damaged areas and to raising environmental awareness. Through this program, site commanders and managers continually have up-to-date information on critical management issues, as well as analysis of trends over time.

In an age of shrinking armed forces and base realignments and closures, the tasks of the remaining military training sites become more difficult and critical. As human demands on natural resources increase, ecologically sound management of public lands becomes equally difficult and critical. Happily, the two missions can coexist.

Brian Duke is Environmental Planner, Army National Guard, Camp Roberts. 


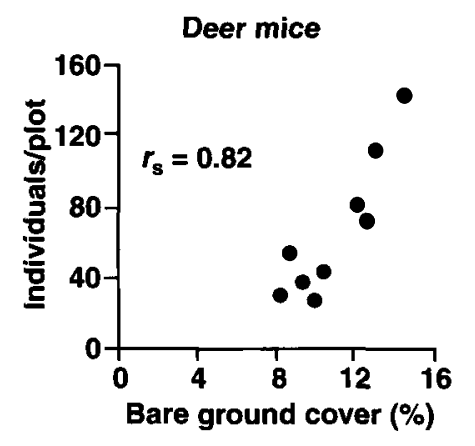

Fig. 3. Total number of individual deer mice captured per plot on nine 14-acre plots in blue oak woodiands of Camp Roberts during fall 1993 and spring and fall 1994-1996.

Habitat relationships. The four most abundant species of amphibians and reptiles were all positively correlated with percent forb cover, percent downed wood cover and litter weight; they were negatively correlated with percent grass cover (table 3). Percent tree canopy cover, percent shrub cover, percent unvegetated ground cover and litter weight were the strongest correlated habitat variables for slender salamanders, gopher snakes, skinks and western fence lizards, respectively (table 3 ). Slender salamanders exhibited the strongest habitat correlations across all habitat variables. Western fence lizards exhibited the weakest habitat correlations across all habitat variables. Only slender salamanders and gopher snakes were significantly correlated with any habitat variables.

\section{Richest in vertebrates}

We were surprised by the high numbers of vertebrates we observed in the oak woodland at Camp Roberts. Our findings support the often-quoted statement that oak woodland is the richest in vertebrate species of the major habitat types that occur in California. For example, in the densest, most well-structured habitats, we caught a small mammal in almost every trap. Compared to other terrestrial vertebrate taxa, oak woodland is unusually rich in bird species. This study supports that finding. The number of territories we documented for plain titmice, dark-eyed juncos and several other species is equal to or greater than the number in any other study of oak woodlands. The high number of

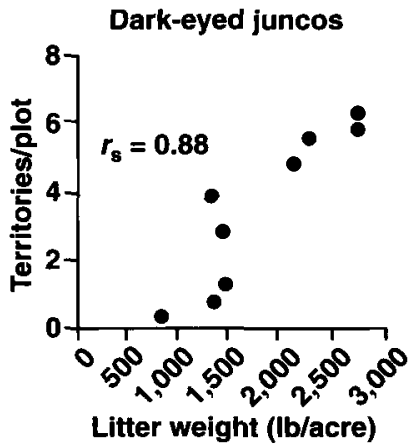

Fig. 4. Average annual number of darkeyed junco territories per plot on nine 14acre plots in blue oak woodlands of Camp Roberts during spring 1994-1996.

detections of herpetofauna under coverboards was also unexpected. Coverboards have proven to be a useful method to sample herpetofauna in our study. They are inexpensive and easy to install, maintain and monitor compared to other sampling techniques, and have obvious applications for rapidly assessing herpetofauna diversity and indexing abundance.

Lacking cause-and-effect relationships, we can only speculate about the habitat relationships of some vertebrate species we observed. With the exceptions of pocket mice and deer mice, shrub cover was important to the six most abundant small mammals we captured. All are woodland species that require dense overhead cover for escape and foraging habitats. The California pocket mouse is a species of open areas; dense ground cover inhibits its movements. Deer mice are habitat generalists (both within and without oak woodland), which probably led to low preference for any measured habitat variables.

Among birds, the amount of ground litter was important to house finches and dark-eyed juncos. Both are ground feeders, and the dark-eyed junco is a ground nester. A welldeveloped litter layer probably supports a large arthropod community for feeding, provides seeds for foraging and provides camouflage for nesting. Plain titmice are foliage gleaners and their association with canopy cover is not unexpected - unlike the negative association of the white-breasted nuthatch with downed wood. The latter is probably a spurious correlation. Our observations indicate that downed

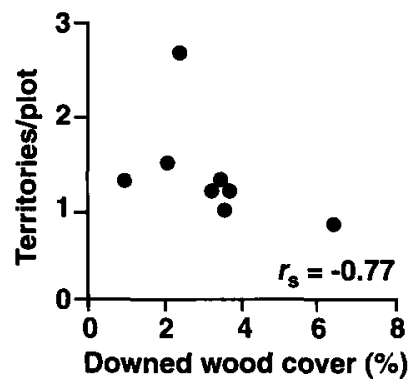

Fig. 5. Average annual number of whitebreasted nuthatch territories per plot on nine 14-acre plots in blue oak woodlands of Camp Roberts during spring 1994-1996.

TABLE 4. Average annual density of breedingbird territories (derived from spot mapping) of 23 bird species on nine 14-acre study plots in oak woodland, Camp Roberts, spring 1994-1996

\begin{tabular}{lc}
\hline \hline Species & $\begin{array}{c}\text { Number of territories } \\
\text { per 100 acres }\end{array}$ \\
\hline Plain titmouse & 46.1 \\
Dark-eyed junco & 24.5 \\
White-breasted nuthatch & 9.6 \\
House finch & 9.0 \\
Hutton's vireo & 5.0 \\
Lesser goldfinch & 4.7 \\
Blue-gray gnatcatcher & 4.4 \\
Lark sparrow & 4.3 \\
California towhee & 3.7 \\
Common bushtit & 3.7 \\
Western bluebird & 3.7 \\
Lawrence's goldfinch & 3.0 \\
Bewick's wren & 2.9 \\
Spotted towhee & 2.9 \\
Nuttall's woodpecker & 1.8 \\
House wren & 1.6 \\
Orange-crowned warbler & 1.3 \\
Northern oriole & 0.7 \\
Northern flicker & 0.5 \\
California quail & 0.3 \\
Acorn woodpecker & 0.1 \\
Brown-headed cowbird & 0.1 \\
Cooper's hawk & 0.1 \\
Total & 148.0 \\
\hline
\end{tabular}

TABLE 5. Amphibians and reptiles observed under 136 coverboards on each of nine 14-acre plots, Camp Roberts, January-April 1995 and 1996

\begin{tabular}{|c|c|c|}
\hline Species & $\begin{array}{c}\text { Total } \\
\text { observations }\end{array}$ & Success* \\
\hline \multicolumn{2}{|l|}{ Lizards } & $\%$ \\
\hline Skink & 1,053 & 3.1 \\
\hline Western fence lizard & 650 & 1.9 \\
\hline California legless lizard & 90 & $<1.0$ \\
\hline Southern alligator lizard & 38 & $<1.0$ \\
\hline Side-blotched lizard & 20 & $<1.0$ \\
\hline \multicolumn{3}{|l|}{ Snakes } \\
\hline Gopher snake & 96 & $<1.0$ \\
\hline Striped racer & 81 & $<1.0$ \\
\hline Common kingsnake & 33 & $<1.0$ \\
\hline Ring-necked snake & 30 & $<1.0$ \\
\hline Nightsnake & 19 & $<1.0$ \\
\hline Garter snake & 8 & $<1.0$ \\
\hline \multicolumn{3}{|l|}{ Salamanders } \\
\hline Slender salamander & 516 & 1.5 \\
\hline Ensatina & 1 & $<1.0$ \\
\hline \multicolumn{3}{|l|}{ Frogs and toads } \\
\hline Pacific tree frog & 14 & $<1.0$ \\
\hline Western toad & 9 & $<1.0$ \\
\hline Total & 2,658 & 7.8 \\
\hline
\end{tabular}

- Success $=$ total observations expressed as a percent of total coverboard checks $(33,728)$. 


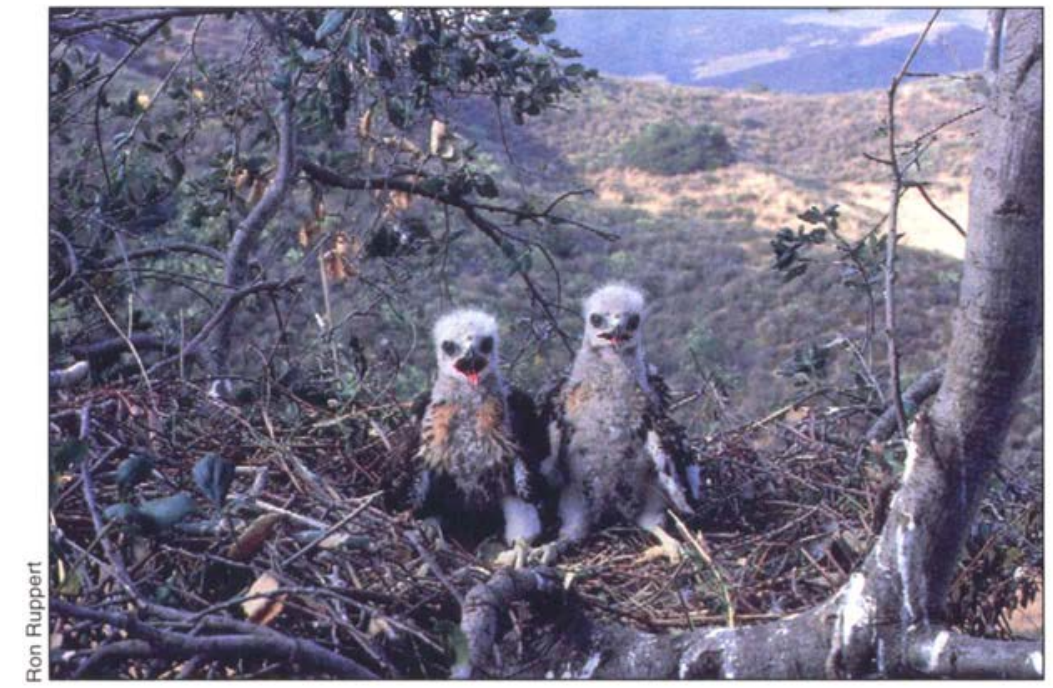

Information from this study may be used as a baseline for evaluating the effects of disturbances - including prescribed burning and wildfire - on dark-eyed juncos and other vertebrate animals that use oak woodland habitats.

wood is more abundant in areas with larger, older, more decadent trees and standing snags, where nuthatches forage and nest; therefore one would expect the relationship to be positive, rather than negative.

The rather weak habitat relationships among herpetofauna observed in this study may suggest that microhabitat characteristics are less important at a certain level to herpetofauna than habitat type on the landscape. Similarly, the scale at which the habitat elements were measured might be inadequate (too large) to pick up strong preferences by these animals for certain elements (for example, slender salamanders with downed wood). Western fence lizards had weak correlations, probably because they are habitat generalists. The strong mean correlation values for slender salamanders and gopher snakes could be related to the relatively high number of observations of those species.

Although we may not have measured the habitat elements most important to these animals, well-structured habitat, including shrubby understory, an accumulation of logs and other downed woody material, and a buildup of ground litter on many of the areas we sampled contributed greatly to the high numbers and high densities of vertebrate species we observed.
In October 1997, the California Department of Forestry and Fire Protection (CDF) and the Camp Roberts Fire Department experimentally burned 500 acres of the study site including half of our plots. Use

of prescribed burning to maintain vegetation at a certain successional stage or to limit fuel buildup is a common management practice in California oak woodland. The experimental burns on the study area might have altered the habitat components we examined, and the vertebrate taxa might respond in an unknown manner and to an unknown degree. Over the next several years, we will monitor the animal responses in an attempt to answer some of the questions posed to land-use planners and land managers when evaluating or predicting the effects of wildfire and prescribed burning on vertebrate fauna. In this way, we hope to develop better management recommendations for California's oak woodlands.

W.D. Tietje is Natural Resources Specialist, Integrated Hardwood Range Management Program (IHRMP), Department of Environmental Science, Policy, and Management, UC Berkeley located at UC Cooperative Extension (UCCE), San Luis Obispo County; and J.K. Vreeland is Staff Research Associate, IHRMP, UCCE San Luis Obispo County.

The authors thank the Army National Guard, Camp Roberts, for allowing access for study purposes. Brian Duke and Julie Eliason, Camp Roberts Environmental Office, and Eva Begley, Senior Environmental Planner, Sacramento, provided assistance and support on the study. Karen Carney, Jo Ann Dockter, John Elliott, Tina Fabula, Debora Guillot, Mike McGovern, Daniel Perry, Kathy Sharum, Nathan Smith and Jane Wooding assisted with fieldwork. The study was funded by UC Integrated Hardwood Range Manage- ment Program Grant 91-003, and California Department of Forestry and Fire Protection Grant 8CA96037. Logistical support was provided by the San Luis Obispo County Cooperative Extension Office. Supplemental funds were provided for fieldwork by the San Luis Obispo County Fish and Game Fines Committee and the Central Coast Resource Conservation and Development Council.

\section{Further reading}

Airola DA. 1988. Guide to the California wildlife habitat relationships system. Prepared for the State of California Resources Agency, Department of Fish and Game. Sacramento, CA. 74 p.

Block WM, Morrison ML. 1990.

Wildlife diversity on the central Sierra foothills. Cal Ag 44(2):19-22.

Block WM, Morrison ML. 1991. Influence of scale on the management of wildlife in California oak woodlands. In: Standiford RB (technical coordinator). Proceedings of the symposium on oak woodlands and hardwood rangeland management; 1990 Oct 31-Nov 2; Davis, CA. Gen. Tech. Rep. No. PSWGTR-126. Berkeley, CA: Pacific Southwest Research Station, Forest Service, U.S. Department of Agriculture. 96-104.

Ehrlich PR, Dobkin DS, Wheye D. 1988. The birder's handbook. New York: Simon and Schuster. $785 \mathrm{p}$.

Johnson S, Tietje WD (technical editor). 1992. Wildlife among the oaks: a management guide for landowners (pamphlet). Berkeley, CA: UC Integrated Hardwood Range Management Program. $16 \mathrm{p}$.

Morrison ML, Block WM, Verner J. 1991. Wildlife-habitat relationships in California's oak woodlands: where do we go from here? In: Standiford, Richard B., technical coordinator. Proceedings of the symposium on oak woodlands and hardwood rangeland management; 1990 Oct 31-Nov. 2; Davis, CA. Gen. Tech. Rep. PSW-GTR126. Berkeley, CA: Pacific Southwest Research Station, Forest Service, U.S. Department of Agriculture. 105-9.

Morrison ML, Marcot BG, Mannan RW. 1992. Wildlife-habitat relationships: concepts and applications. Madison, WI: University of Wisconsin Press. 343 p. 